Supplement of Biogeosciences, 17, 6441-6456, 2020 https://doi.org/10.5194/bg-17-6441-2020-supplement (C) Author(s) 2020. This work is distributed under the Creative Commons Attribution 4.0 License.

(c) (1)

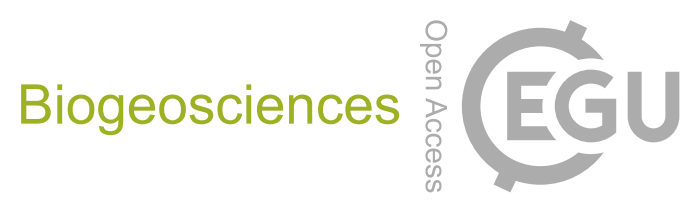

Supplement of

\title{
A bottom-up quantification of foliar mercury uptake fluxes across Europe
}

Lena Wohlgemuth et al.

Correspondence to: Lena Wohlgemuth (lena.wohlgemuth@unibas.ch) and Martin Jiskra (martin.jiskra@unibas.ch)

The copyright of individual parts of the supplement might differ from the CC BY 4.0 License. 


\section{S1: Overview of parameters associated with the ten forest research sites}

Table S1: Summary of exact location and associated parameters of the ten study sites

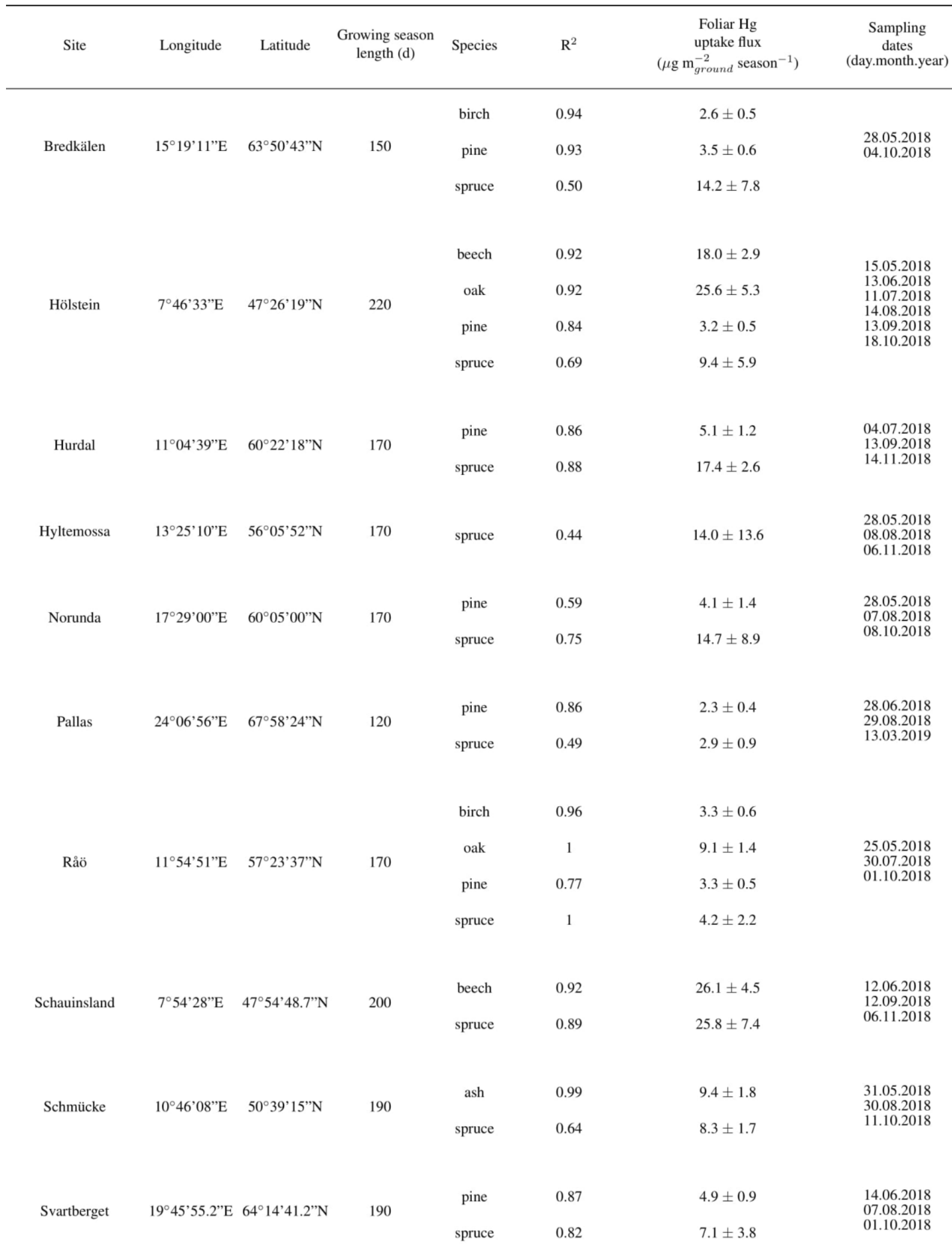


S2: Average LAI values for six tree species (birch, beech, ash, spruce, pine and oak)

Table S2: Average LAI values $\left(\mathrm{m}^{2}\right.$ leaf $\mathrm{m}^{-2}$ ground $)$ derived from Iio and Ito (2014) with standard deviation, standard error and number of values (n)

\begin{tabular}{lcccc} 
Species & average LAI value & standard dev. LAI value & rel. standard error LAI value & n \\
\hline birch & 2.6 & 1.22 & 0.19 & 40 \\
beech & 7.0 & 1.57 & 0.19 & 70 \\
ash & 3.1 & 0.55 & 0.13 & 2 \\
spruce & 7.3 & 2.12 & 0.32 & 45 \\
pine & 2.9 & 1.37 & 0.25 & 31 \\
oak & 4.9 & 1.66 & 0.33 & 25
\end{tabular}

S3: Foliar Hg concentration after drying at different temperatures

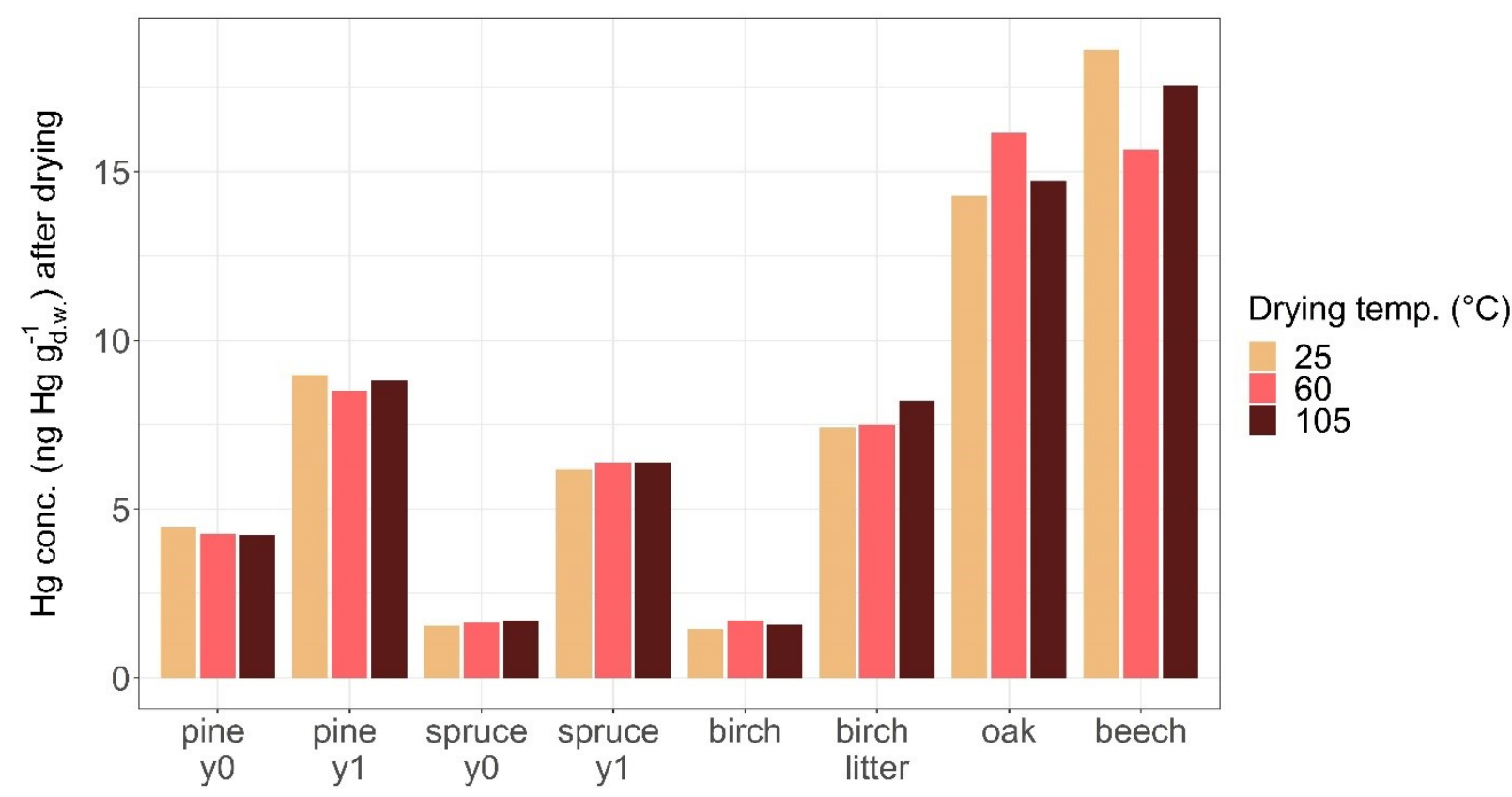

Fig. S1: $\mathrm{Hg}$ concentration ( $\mathrm{ng} \mathrm{g}^{-1}$ d.w.) measured in 3 subsamples of 8 independent foliar samples of various tree species and needle age classes. Each respective subsample was dried at either $25^{\circ} \mathrm{C}, 60^{\circ} \mathrm{C}$ or $105^{\circ} \mathrm{C}$ for 24 hours prior to $\mathrm{Hg}$ measurement. Resulting $\mathrm{Hg}$ concentrations were all corrected for water content to make them comparable. 


\section{S4: Details on measurements of needle area}

\section{S4.1 Calibration of the LI3100 for needles}

We used a LI3100 Area Meter (LI-COR Biosciences USA) for measuring projected areas of both leaf and needle samples. The per cent deviation between scans and duplicate scans was $3 \% \pm 3 \%$. Scans of projected leaf areas produced robust results. The accuracy of needle scans, however, proved challenging due to the high ratio of edge to area of needles. We thus calibrated the LI3100 applying round rubberized pieces of wires of known length and a diameter of $1.74 \pm 0.02 \mathrm{~mm}$ as standard material to simulate needle phenology. Projected areas of the rubberized wires were verified by scanning the wires to a digital image and applying image recognition software to calculate the projected wire area. Calibration curves revealed that values for projected areas of standard material measured at the LI3100 met only $60 \%$ of respective target values (Fig. S2). We suspect that the light sensor of the LI3100 is not able to fully resolve thin needles and thus recommend to use different area scanning devices with a higher accuracy for needle geometry in future studies. In order to obtain needle area values as accurate as possible given the low resolution of needles at the LI3100, we replaced, where possible, needle area values with values determined by research staff (Hyltemossa, Norunda and Svartberget; see S4.2) or with literature values at two sites (Hurdal and Pallas) where the LI3100 produced faulty and unrealistic results (S4.3).

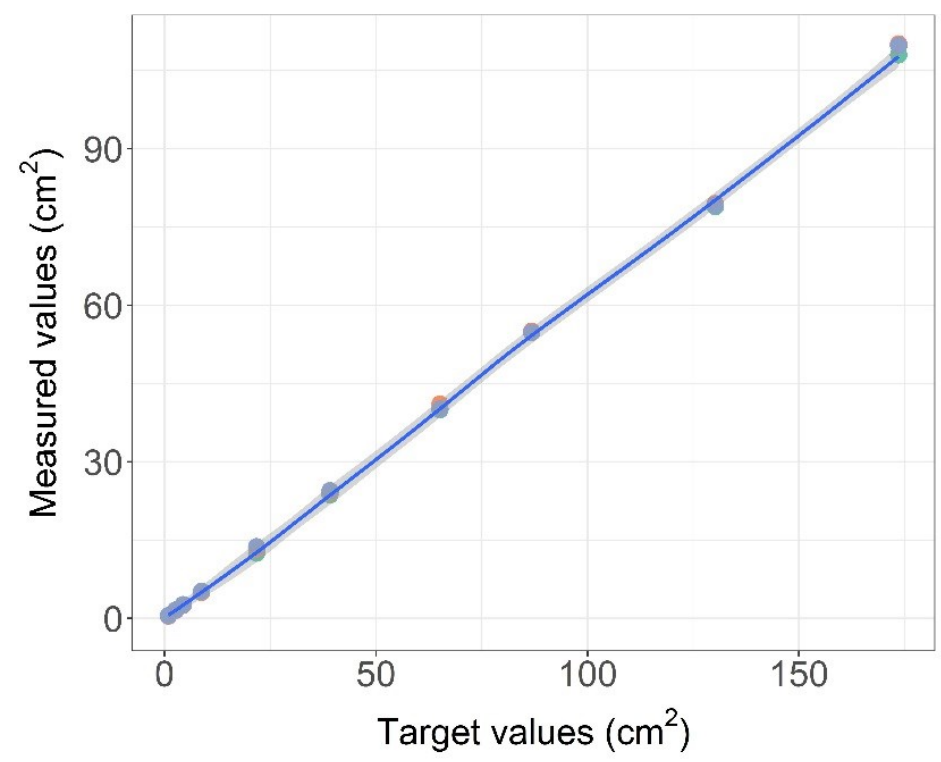

Fig. S2: Calibration curve of needle shaped rubberized standard materials of known projected area $\left(\mathrm{cm}^{2}\right)$ measured at a LI3100 Area Meter.

\section{S4.2 Projected needle area values from ICOS stations}

At the Swedish ICOS stations Hyltemossa, Norunda and Svartberget projected areas and LMA of pine and spruce needles from the 2018 growing season were determined by research staff (Loustau et al., 2018). Given the low resolution of thin needles by the LI3100 (Sect. S4.1) we suspected that the ICOS needle area values are closer to true values than our values. We thus multiplied the foliar $\mathrm{Hg}$ uptake rates $\left(\mathrm{ng} \mathrm{Hg} \mathrm{g}^{-1}\right.$ d.w. month $^{-1}$ ) of tree species at Hyltemossa, Norunda and Svartberget with the average LMA values of tree species at the 3 sites respectively to obtain foliar $\mathrm{Hg}$ uptake rates normalized to projected needle area $\left(\mathrm{ng} \mathrm{Hg} \mathrm{m}^{-2}\right.$ needle area month $\left.{ }^{-1}\right)$. The average LMA of 2018 spruce needles at Hyltemossa was $331 \mathrm{~g}^{-1}$ d.w. $\mathrm{m}^{2}$ needle area. The average LMA of pine and spruce needle areas at Norunda was $129 \mathrm{~g}^{-1}$ d.w. $\mathrm{m}^{2}$ needle area and $179 \mathrm{~g}^{-1}$ d.w. $\mathrm{m}^{2}$ needle area respectively. At average Svartberget the LMA of pine and spruce needle areas was $192 \mathrm{~g}^{-1}$ d.w. $\mathrm{m}^{2}$ needle area and $189 \mathrm{~g}^{-1}$ d.w. $\mathrm{m}^{2}$ needle area respectively. 


\section{S4.3 Projected needle areas from samples of Hurdal and Pallas}

Needle areas of needles collected at the research sites Hurdal and Pallas and measured at the LI3100 were exceptionally low resulting in relatively high average LMA values (mass over area) of $704 \pm 144 \mathrm{~g}_{\text {d.w. }} \mathrm{m}^{-2}$ needle area and $680 \pm 332 \mathrm{~g}$ d.w. $\mathrm{m}^{-2}$ needle area respectively. The average LMA value of needles of all other sites was $246 \pm 74 \mathrm{~g}_{\mathrm{d} . w .} \mathrm{m}^{-2}$ needle area. We defined an acceptable LMA threshold value of $475 \mathrm{~g}_{\text {d.w. }} \mathrm{m}^{-2}$ needle area which corresponds to the $90^{\text {th }}$ percentile value from 70 LMA values of evergreen gymnosperm foliage compiled by Poorter et al. (2009). We thus discarded needle areas of samples from Hurdal and Pallas due to faulty performance of the LI3100 at the particular measurement days which might be the result of unrecorded dirtying of the area meter conveyer belt but could not be reconstructed in retrospect. For the LMA values of needle samples from Hurdal and Pallas we thus used the median LMA value of $227 \mathrm{~g}_{\text {d.w. }} \mathrm{m}^{-}$ ${ }^{2}$ needle area for evergreen gymnosperms following Poorter et al. (2009).

\section{S5: Needle Hg concentrations of multiple needle age classes}



Fig. S3: $\mathrm{Hg}$ concentrations ( $\mathrm{ng} \mathrm{g}^{-1}$ d.w.) in spruce and pine needles of various age classes sampled at the end of the 2018 growing season (October - November). Age class 0 represents current season needles, age classes 1, 2 and 3 one-, two- and three-year old needles respectively. Error bars denote one standard deviation between needle age samples of multiple trees at each site. 


\section{S6: Details on analysis of needle age correction factors ( $\mathrm{cf}_{\text {age }}$ )}

$\mathrm{Cf}_{\text {age }}$ allows to scale up $\mathrm{Hg}$ uptake flux determined in $\mathrm{y}_{0}$ needles to $\mathrm{Hg}$ uptake flux in needles of all age classes (Eq. 4). For calculating needle age correction factors ( $\mathrm{cf}_{\text {age }}$ ) according to Eq. 3 we used i) RAR values averaged over Bavarian sampling sites and sampling years (spruce: 9 sampling sites in 2015 and 10 sampling sites in 2017; pine: 2 sampling sites in 2015 and 2017 respectively) determined in our systematic needle analysis (Fig 4) and ii) the relative biomass (RB) of each spruce needle age class from literature (Matyssek et al., 1995) (Table S3). For pine we assumed that fully grown needle age classes ( $\mathrm{y}_{0}$ to $\mathrm{y}_{2}$ ) exhibit equal RBs, thus RB for three pine needle age classes is 0.33 respectively (Table S3). Standard error of $\mathrm{cf}_{\text {age }}$ was determined by error propagation of RAR standard errors, see Section S13.

Table S3: Species-specific correction factors for needle age ( $\left.\mathrm{cf}_{\mathrm{age}}\right)$ allowing to scale up $\mathrm{Hg}$ uptake fluxes of current-season ( $\left.\mathrm{y}_{0}\right)$ needles to $\mathrm{Hg}$ uptake fluxes of needles of all age classes (Eq. 4). RAR is the relative $\mathrm{Hg}$ accumulation rate of respective needle age class normalized to $\mathrm{Hg}$ accumulation rate of $\mathrm{y}_{0}$ needles determined in our systematic needle analysis as average over sampling sites and sampling years. RB is the relative biomass of each needle age class to total biomass determined for spruces by Matyssek et al. (1995). Final needle age correction factor, cf age, was calculated according to Eq. 3.

\begin{tabular}{lllll}
\hline Tree species & Needle age class & $\begin{array}{l}\text { RAR } \\
\text { (mean } \pm \mathbf{s e )}\end{array}$ & RB & $\begin{array}{l}\text { cfage } \\
\text { (factor } \pm \text { se) }\end{array}$ \\
\hline spruce & $\mathrm{y}_{0}$ & 1 & 0.195 & $0.79 \pm 0.03$ \\
& $\mathrm{y}_{1}$ & $0.95 \pm 0.05$ & 0.19 & \\
& $\mathrm{y}_{2}$ & $0.90 \pm 0.05$ & 0.18 & \\
& $\mathrm{y}_{3}$ & $0.84 \pm 0.06$ & 0.14 & \\
& $\mathrm{y}_{4}$ & $0.55 \pm 0.11$ & 0.17 & \\
& $\mathrm{y}_{5}$ & $0.45 \pm 0.08$ & 0.075 & $0.86 \pm 0.06$ \\
& $\mathrm{y}_{6}$ & $0.13 \pm 0.14$ & 0.05 & \\
\hline pine & $\mathrm{y}_{0}$ & 1 & 0.33 & \\
& $\mathrm{y}_{1}$ & $0.99 \pm 0.19$ & 0.33 & \\
\hline $\mathrm{y}_{2}$ & 0.65 & 0.33 & \\
\hline
\end{tabular}




\section{S7: Details on $\mathrm{Hg}(0)$ air measurements using passive air samplers (PAS)}

We attached Hg passive air samplers (PAS) to the ceiling of the crane installed at Hölstein at heights of $35 \mathrm{~m}, 19 \mathrm{~m}$, $10 \mathrm{~m}$ and to four trees at a height of $1.6 \mathrm{~m}$ respectively (Fig. S4). Each PAS comprised a sulfur-impregnated activated carbon (AC) sorbent with a white Radiello $($ C diffusive housing inside a protective jar. The application of PAS is described in detail by McLagan et al. (2016, 2017b). We conducted two PAS campaigns. The PAS exposure period of the 2018 campaign was 156 days between 15 May to 18 October 2018 and the 2019 campaign lasted 119 days from 16 May to 12 September 2019. We calculated atmospheric $\mathrm{Hg}(0)$ concentrations by dividing the total $\mathrm{Hg}$ content measured in AC of each PAS respectively by the corresponding exposure period (156 days in 2018 or 119 days in 2019) and a sampling rate of $0.135 \mathrm{~m}^{3}$ day $^{-1}$ calibrated by (McLagan et al., 2018). However, meteorological parameters like wind speed and temperature may slightly impact sampling rate. For every $\mathrm{m} \mathrm{s}^{-1}$ increase in wind speed and every $1^{\circ} \mathrm{C}$ (McLagan et al., 2017b) found an increase of sampling rate of $2.5 \%$ and $0.7 \%$ respectively. Higher wind speeds above canopy than at understory height level results in an increase of sampling rate of PAS at $35 \mathrm{~m}$ compared to PAS at $1.6 \mathrm{~m}$ and thus a decrease in gradient of atmospheric $\mathrm{Hg}(0)$ above canopy to understory.

Analysis of AC for total Hg content was performed using a DMA-80 (Milestone, Heerbrugg, Switzerland) according to sampling operation procedure described in section 2.3. Total AC of each PAS was analyzed for Hg at the DMA-80 in aliquots of two and $\mathrm{Na}_{2} \mathrm{CO}_{3}$ was added to each sampling boat following a recommendation by (McLagan et al., 2017a). Standard reference material of AC for the 2018 campaign was produced manually. For this purpose we extracted $280 \mu \mathrm{l}$ of $\mathrm{Hg}$ vapor stabilized at $20^{\circ} \mathrm{C}$ (corresponding to $3.7 \mathrm{ng} \mathrm{Hg}$ ) using a gas tight syringe (Hamilton Company) from a mercury vapor primary calibration unit (Tekran ${ }^{\circledR}$ Model 2505, Inc. Toronto, Canada). We injected the $\mathrm{Hg}$ vapor into an airtight Teflon tube attached to a glass tube filled with approximately $400 \mathrm{mg}$ of AC. An attached pump drew the injected $\mathrm{Hg}$ vapor through the $\mathrm{AC}$ resulting in an adsorption of $\mathrm{Hg}$ to the $\mathrm{AC}$. The average recovery of $\mathrm{Hg}$ in AC SRMs was $0.92 \pm 0.13$ (mean $\pm \mathrm{sd}, \mathrm{n}=6$ ). For measuring $\mathrm{Hg}$ in $\mathrm{AC}$ of our 2019 campaign we applied the bituminous coal standard NIST2685c and found an average recovery of $1.02 \pm 0.08$ (mean $\pm \mathrm{sd}, \mathrm{n}=7$ ). We were not able to perform a blank correction in 2018 as our field blanks got contaminated when accidentally storing them in a cupboard where $\mathrm{Hg}$ air concentrations were elevated probably due to legacy $\mathrm{Hg}$ which we confirmed by measuring air $\mathrm{Hg}$ using active instruments. In 2019 we analyzed a field blank which consisted of one PAS brought to the field at the beginning of the deployment period, opened, closed immediately again and stored until analysis together with deployed PAS. The 2019 PAS samples were blank adjusted by multiplying the field blank concentration with each sample AC mass and substracting the result from the mass of $\mathrm{Hg}$ sorbed on the respective AC.
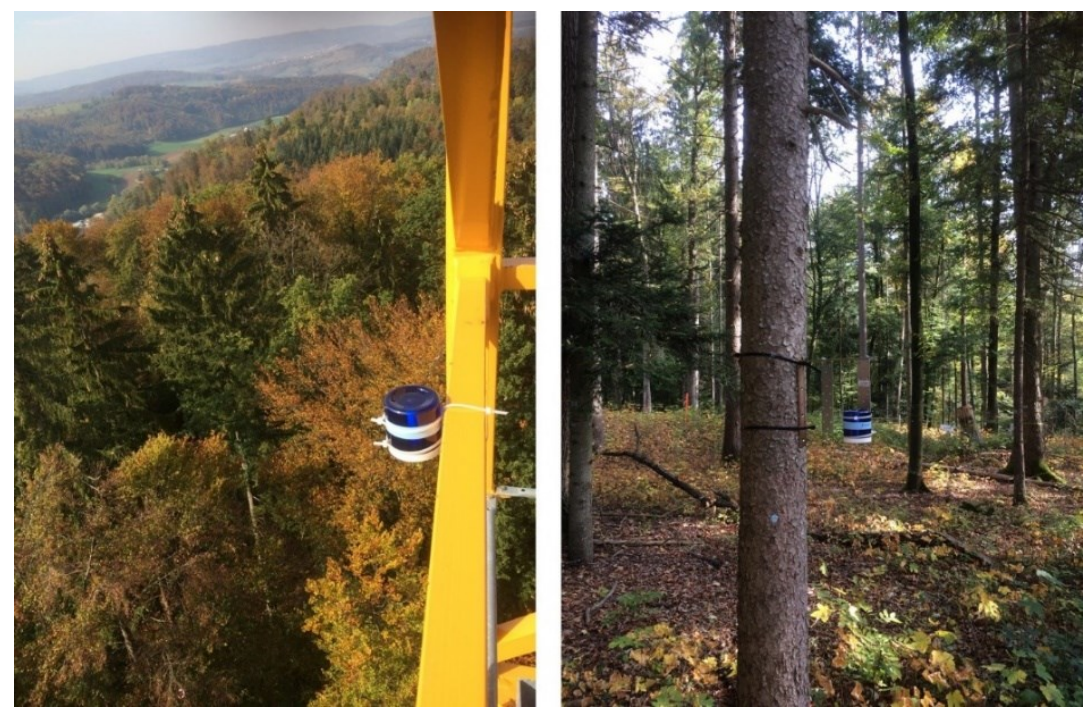

Fig. S4: Mounting of mercury passive air samplers (PAS) at the crane ceiling above canopy (left) and at a tree at ground level (right) at the Hölstein research site 


\section{S8: Foliar Hg concentrations in Hölstein at peak season (August)}

At the experimental mixed forest site Hölstein we sampled different types of foliage side by side allowing for comparison of foliar $\mathrm{Hg}$ concentrations between tree functional groups (deciduous leaves vs. coniferous needles). Deciduous beech and oak leaves exhibited higher $\mathrm{Hg}$ concentrations than coniferous pine and spruce needles of the same age (current season, Table S4). However, average Hg concentrations in multi-year old needles (one to three year old) approached average $\mathrm{Hg}$ concentrations of leaves because needles accumulate $\mathrm{Hg}$ over their whole life cycle (see $3.1)$.

Table S4: Mean \pm SD ( $\mathrm{n}=$ number of sampled trees) of foliar $\mathrm{Hg}$ concentration $\left(\mathrm{ng} \mathrm{Hg} \mathrm{g}^{-1}\right.$ d.w.) in four types of foliage at Hölstein in August. Foliage was sampled at top of canopy.

\begin{tabular}{lcccc} 
Foliage type & Current season $\left(\mathrm{y}_{0}\right)$ & 1-year old $\left(\mathrm{y}_{1}\right)$ & 2-year old $\left(\mathrm{y}_{2}\right)$ & 3-year old $\left(\mathrm{y}_{3}\right)$ \\
\hline beech leaves & $21.6 \pm 2.9(\mathrm{n}=3)$ & - & - & - \\
oak leaves & $22.7 \pm 4.1(\mathrm{n}=4)$ & - & - & - \\
pine needles & $6.5 \pm 0.6(\mathrm{n}=2)$ & $13.2 \pm 3.1(\mathrm{n}=3)$ & not sampled & - \\
spruce needles & $8.1 \pm 2.2(\mathrm{n}=3)$ & $12.8 \pm 1.3(\mathrm{n}=3)$ & $20.2 \pm 5.5(\mathrm{n}=2)$ & $\mathbf{2 6 . 6} \pm \mathbf{7 . 4}(\mathrm{n}=\mathbf{2})$
\end{tabular}

\section{S9: Foliar Hg pool calculation for coniferous trees}

When assessing the foliar $\mathrm{Hg}$ pool of coniferous trees, $\mathrm{Hg}$ levels in needles of all age classes present at coniferous trees have to be taken into account. Consequently, $\mathrm{Hg}$ levels in each needle age class (weighted by their respective relative biomass RB) have to be added up. As an example calculation, we determined the spruce needle Hg pool of the boreal forest at Pallasjärvi in Northern Finland which is part of the atmosphere-ecosystem research site Pallas. To this end, we used the $\mathrm{Hg}$ concentration of current season ( $\mathrm{y}_{0}$ ) spruce needles sampled in Pallas in August 2018 which was 10.4 $\pm 1.5 \mathrm{ng} \mathrm{Hg} \mathrm{g}_{\text {d.w. }}$ (mean $\pm \mathrm{sd} ; \mathrm{n}=5$ sampled spruce trees). By multiplying the mean $\mathrm{Hg}$ concentration of $\mathrm{y}_{0}$ needles by the Hg relative accumulation rate (RAR; see S6 Table S3) of each spruce needle age class $\mathrm{y}_{1}$ to $\mathrm{y}_{6}$ respectively, we derived theoretic $\mathrm{Hg}$ concentration gains (that is, quantities of $\mathrm{Hg}$ accumulated from the start of the growing season

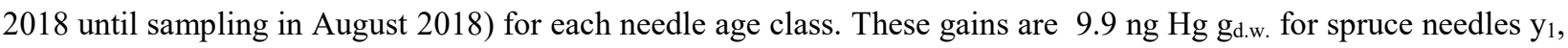
$9.4 \mathrm{ng} \mathrm{Hg} \mathrm{g}_{\text {d.w. }}$ for spruce needles $\mathrm{y}_{2}, 8.8 \mathrm{ng} \mathrm{Hg} \mathrm{g}_{\text {d.w. }}$ for spruce needles $\mathrm{y}_{3}, 5.7 \mathrm{ng} \mathrm{Hg} \mathrm{g}_{\text {d.w. }}$ for spruce needles $\mathrm{y}_{4}, 4.7 \mathrm{ng}$ $\mathrm{Hg}_{\mathrm{g}} \mathrm{g}_{\text {d.w. }}$ for spruce needles $\mathrm{y}_{5}$ and $1.4 \mathrm{ng} \mathrm{Hg} \mathrm{g}_{\text {d.w. }}$ for spruce needles $\mathrm{y}_{6}$. Using these gains, we estimated total $\mathrm{Hg}$ concentrations in each needle age class $\mathrm{y}_{\mathrm{i}}$ by incrementally summing up the $\mathrm{Hg}$ concentration gains of needles $\mathrm{y}_{\mathrm{i}}$ with $\mathrm{Hg}$ concentration gains of needles $\mathrm{y}_{\mathrm{i}-1}$. This results in a total $\mathrm{Hg}$ concentration of $10.4 \mathrm{ng} \mathrm{Hg} \mathrm{g}_{\text {d.w. }}$ for needles $\mathrm{y}_{0}, 20.6$ $\mathrm{ng} \mathrm{Hg} \mathrm{g}_{\text {d.w. }}$ for needles $\mathrm{y}_{1}, 29.8 \mathrm{ng} \mathrm{Hg} \mathrm{g}_{\text {d.w. }}$ for needles $\mathrm{y}_{2}, 38.6 \mathrm{ng} \mathrm{Hg} \mathrm{g}_{\text {d.w. }}$ for needles $\mathrm{y}_{3}, 44.3 \mathrm{ng} \mathrm{Hg} \mathrm{g}_{\text {d.w. }}$ for needles $\mathrm{y}_{4}, 49.0 \mathrm{ng} \mathrm{Hg} \mathrm{g}_{\text {d.w. }}$ for needles $\mathrm{y}_{5}$ and $50.3 \mathrm{ng} \mathrm{Hg} \mathrm{g}_{\text {d.w. }}$ for needles $\mathrm{y}_{6}$. To calculate the $\mathrm{Hg}$ concentration pool representive for all spruce needles present, we weighted total $\mathrm{Hg}$ concentrations of each needle age class with their respective relative biomass (S6, Table S3) and summed up all resulting values. This resulted in a spruce needle concentration pool of $30.4 \mathrm{ng} \mathrm{Hg} \mathrm{g}_{\text {d.w. }}$ which is close to the range of $\mathrm{Hg}$ concentrations in deciduous leaves (see for example S8, Table S4). In a final step, we obtained a foliar $\mathrm{Hg}$ pool normalized to $\mathrm{m}^{2}$ ground area by multiplying the concentration pool with an LMA value of $227 \mathrm{~g}_{\text {d.w. }} \mathrm{m}^{-2}$ needle area (median LMA value used for Pallas, see S4.3) and an LAI value of $3 \mathrm{~m}^{2}$ leaf $\mathrm{m}^{-2}$ ground (retrieved from PROBA-V satellite LAI product for Pallasjärvi in August 2017). The final spruce needle $\mathrm{Hg}$ pool equals $20.7 \mu \mathrm{g} \mathrm{Hg} \mathrm{m}^{-2}$ ground. 


\section{S10: Hg content per leaf area at various tree heights of beech and oak at Hölstein}

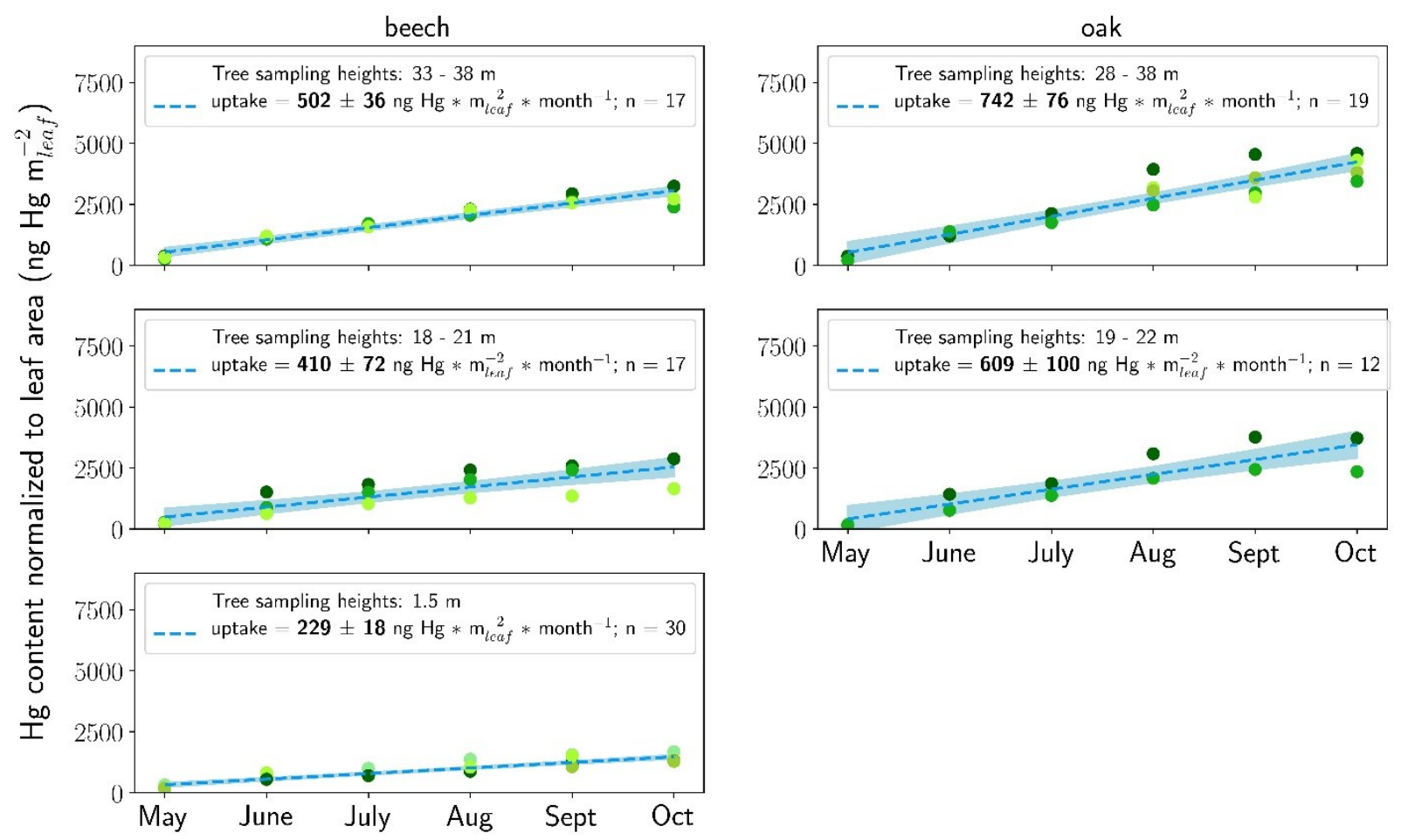

Fig. S5: Increasing $\mathrm{Hg}$ content normalized to leaf surface area $\left(\mathrm{ng} \mathrm{Hg} \mathrm{m}^{-2}\right.$ leaf month $\left.^{-1}\right)$ in leaves of beech trees (left column) and oak trees (right column) at Hölstein over the 2018 growing season. Trees were sampled vertically from top canopy height (top row; $28-38 \mathrm{~m}$ above ground level) to mid canopy height (middle row; $18-22 \mathrm{~m}$ above ground level) to ground level (bottom row; chest height of approximately $1.5 \mathrm{~m}$ above ground level).

\section{S11: Details on analysis of tree height correction factors ( $\mathbf{c f}_{\text {height }}$ )}

We determined a crown height correction factor ( $\mathrm{cf}_{\text {height }}$ ) in order to scale up the foliar $\mathrm{Hg}$ uptake flux at canopy level to whole tree foliage. $\mathrm{Cf}_{\text {height }}$ equals the multiplication of the ratio $\mathrm{r}_{\text {conc. coeff. and }} \mathrm{r}_{\mathrm{LMA}}$ (Eq. 5). In Hölstein $\mathrm{r}_{\text {conc. coeff. was }}$ $1.31 \pm 0.10($ ratio $\pm \mathrm{se}$ ) for beech, $1.11 \pm 0.12($ ratio $\pm \mathrm{se}$ ) for oak and $1.13 \pm 0.10($ ratio \pm se) for spruce (Table S4). The ratio $r_{L M A}$ equals the average LMA values of foliage samples growing at ground/mid canopy level to corresponding LMA values at top canopy level. We determined $r_{\text {LMA }}$ two times with different data by using i) LMA values measured at different tree heights in Hölstein and ii) LMA values from literature (Eriksson et al., 2005; Stancioiu and O'Hara, 2006). $R_{\text {LMA }}$ calculated by using LMA values from Hölstein was $0.36 \pm 0.06$ (ratio $\pm \mathrm{se}$ ) for beech, $0.78 \pm 0.08$ (ratio \pm se) for oak and $0.63 \pm 0.07$ (ratio \pm se) for spruce (Table S4). Changing LMA values with tree height are the result of changing foliage morphology with tree height which in turn is a function of changing sun light availability with tree height (Section 3.2). Consequently, LMA (or its inverse specific leaf area, SLA) may be conceived as an indirect function of available sun light. Stancioiu and O'Hara (2006) determined SLA values as a function of percentage of above canopy light (PACL) for beech, spruce and fir. Under the assumption that light at ground level equals $10 \%$ and light at canopy level equals $90 \%$ of ambient light, $\mathrm{r}_{\mathrm{LMA}}$ derived from Stancioiu and O'Hara (2006) is $0.43 \pm 0.18$ (ratio \pm se) for beech and $0.61 \pm 0.24$ (ratio \pm se) for spruce. For oak trees we calculated an $\mathrm{r}_{\mathrm{LMA}}$ of 0.62 from data by 
(Eriksson et al., 2005). Thus $\mathrm{r}_{\text {LMA }}$ values derived from Eriksson et al. (2005); Stancioiu and O'Hara (2006) are in the same range as average $r_{\text {LMA }}$ values determined in Hölstein. As functions of inverse LMA with PACL by Stancioiu and O'Hara (2006) were more generically determined for a range of trees of various heights, diameters and ages we used values from Eriksson et al. (2005); Stancioiu and O'Hara (2006) for all sites where foliage samples were taken at crown level (Hyltemossa, Norunda and Svartberget) except Hölstein. Pine was excluded from the analysis as pine trees in Hölstein exclusively grew needles in the canopy and pine on average exhibit LAI values $<3$ (Table S2). Standard errors of $r_{\text {conc.coeff., }} r_{\text {LMA }}$ and $\mathrm{cf}_{\text {height }}$ were determined by error propagation, see Section $\mathrm{S} 13$.

Table S5: Species-specific factors (cfheight; Eq. 5) correcting foliar Hg uptake fluxes (Eq. 6) for tree height effects originating from changes in linear regression coefficients of foliar $\mathrm{Hg}$ concentration over time with tree height (represented by the ratio rconc. coeff.) and changes of LMA with tree height (represented by the ratio rLMA). RLMA was calculated two times by using data from Hölstein (Hölstein $r_{\text {LMA }}$ ) and by using a function of inverse LMA with available sun light from literature (lit. $\left.r_{L M A}\right)$

\begin{tabular}{llllll}
\hline Tree species & $\begin{array}{l}\mathbf{r}_{\text {conc. coeff. }} \\
(\text { ratio } \pm \text { se) }\end{array}$ & $\begin{array}{l}\text { Hölstein } \mathbf{r}_{\text {LMA }} \\
(\text { ratio } \pm \text { se) }\end{array}$ & $\begin{array}{l}\text { lit. } \mathbf{r}_{\text {LMA }} \\
(\text { ratio } \pm \text { se) }\end{array}$ & $\begin{array}{l}\text { Hölstein cf } \\
\text { (ratio } \pm \text { se) }\end{array}$ & $\begin{array}{l}\text { lit. cf } \\
\text { (ratio } \pm \text { se) }\end{array}$ \\
\hline Beech & $1.31 \pm 0.10$ & $0.36 \pm 0.06$ & $0.43 \pm 0.18$ & $0.47 \pm 0.12$ & $0.56 \pm 0.20$ \\
Oak & $1.13 \pm 0.10$ & $0.78 \pm 0.08$ & 0.62 & $0.88 \pm 0.13$ & 0.70 \\
Spruce & $1.11 \pm 0.12$ & $0.63 \pm 0.07$ & $0.61 \pm 0.24$ & $0.70 \pm 0.14$ & $0.68 \pm 0.27$ \\
\hline
\end{tabular}

S12: Tree species abundance at canopy sampling sites

Table S6: Approximate abundance of tree species to each other at Hölstein and three Swedish ICOS sites where foliage samples were obtained from top canopies.

\begin{tabular}{lll}
\hline Site & Tree species & $\begin{array}{l}\text { Tree species abundance } \\
\text { to each other }\end{array}$ \\
\hline Hölstein & beech & 0.53 \\
& oak & 0.05 \\
& pine & 0.11 \\
& spruce & 0.31 \\
\hline Hyltemossa & spruce & 1.0 \\
\hline Svarunda & pine & 0.47 \\
& spruce & 0.53 \\
\hline
\end{tabular}




\section{S13: Foliar $\mathrm{Hg}$ uptake fluxes of $\mathrm{Hg}$ at the ten research sites}

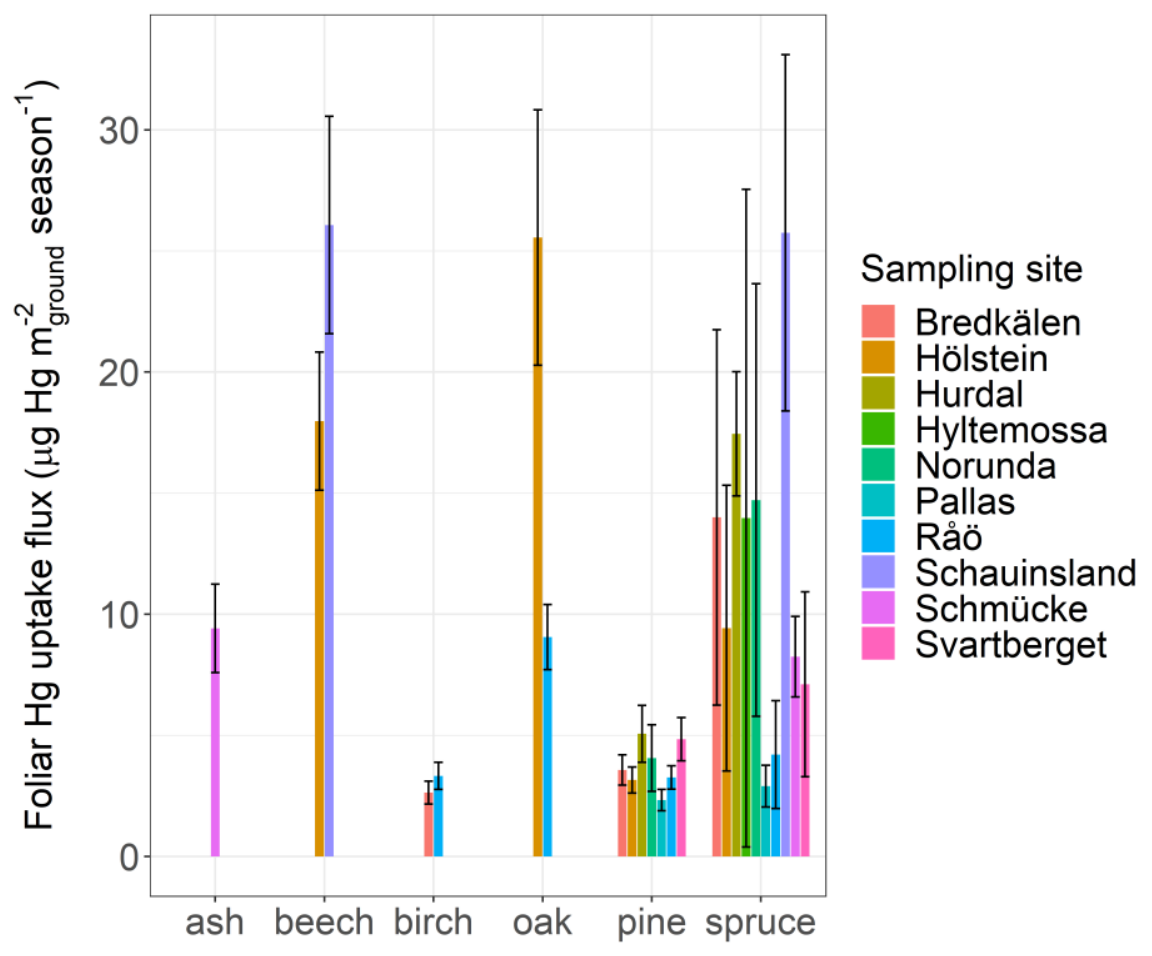

Fig. S6: Foliar Hg uptake fluxes ( $\mu \mathrm{g} \mathrm{Hg} \mathrm{m}^{-2}$ during the 2018 growing season) of 6 tree species at 10 forested research sites in Europe

\section{S14: Details on extrapolation of foliar Hg uptake fluxes to Europe and global temperate forests}

We extrapolated foliar Hg uptake fluxes from this study to the forested land area of Europe and globally to the area of temperate forests. This was performed by 1) weighting average Hg uptake fluxes of each tree species (beech, oak, spruce, pine) at Hölstein, Hyltemossa, Norunda and Svartberget with the respective relative abundance of tree species in Europe and 2) multiplying the resulting average Hg uptake flux with the forested land area of Europe or the land area of global temperate forests respectively. The relative proportion of tree species to each other in Europe was derived from Brus et al. (2012) who analyzed the spatial distribution of 20 tree species in Europe by combining national forest inventories with ICP Forests Level I plot data. Derived from Brus et al. (2012) the relative proportion is 0.11 for beech, 0.10 for oak, 0.36 for spruce and 0.44 for pine. We evaluated the total forested area of Europe to amount to $192.672 \times$ $10^{6}$ hectares (ha) which is the sum of the forested area reported for the EU28 $\left(160.931 \times 10^{6}\right.$ ha; comprising the EU countries as in 2015 including the United Kingdom) (Eurostat, 2015), Norway (12.141 $\times 10^{6}$ ha) (NIBIO, 2016), Ukraine $\left(9.657 \times 10^{6} \mathrm{ha}\right)(\mathrm{FAO}, 2014 \mathrm{~b})$, Belarus $\left(8.633 \times 10^{6} \mathrm{ha}\right)(\mathrm{FAO}, 2014 \mathrm{a})$ and Switzerland $\left(1.31 \times 10^{6} \mathrm{ha}\right)$ (Rigling and Schaffer, 2015). The global land area of temperate forests is approximately $1.04 \times 10^{9}$ ha (Tyrrell et al., 2012). 


\section{S15: Uncertainty assessment of foliar $\mathrm{Hg}$ uptake fluxes and of flux extrapolation}

We calculated the relative standard error of foliar $\mathrm{Hg}$ uptake fluxes per site and tree species (rel.se flux) by error propagation of i) the relative standard error of the regression slope of $\mathrm{Hg}$ content in foliage of all sampled trees (per site and tree species) normalized to leaf area over sampling time (rel.se uptake) and ii) the relative standard error of mean LAI values (per tree species) from literature (rel.se $e_{\text {LAI }}$ ). For coniferous tree species and for sampling sites where foliage samples had been obtained from top canopy (Hölstein, Hyltemossa, Norunda, Svartberget) we additionally propagated the relative standard error of mean needle age correction factor $\left(\mathrm{rel}_{\mathrm{se}} \mathrm{ege}_{\mathrm{age}}\right)$ and the relative standard error of mean tree height correction factor (per tree species) ( rel.se $_{\text {height }}$ ).

Uncertainty assessment for deciduous (tree species at sites where foliage samples where not strictly taken from top canopy is calculated according to error propagation rule (Ku, 1966; Papula, 2003):

$$
\text { rel.se } e_{\text {flux; deciduous }}=\sqrt{\left(\text { rel.se } e_{\text {uptake }}\right)^{2}+\left(\text { rel.se } e_{\text {LAI }}\right)^{2}}
$$

The foliar $\mathrm{Hg}$ uptake flux coniferous tree species is corrected for the presence of various needle age classes and thus the error propagation is extended to

$$
\text { rel.se } e_{\text {flux } ; \text { conifer }}=\sqrt{\left(\text { rel.se } e_{\text {uptake }}\right)^{2}+\left(\text { rel.se } e_{\text {LAI }}\right)^{2}+\left(\text { rel.se } e_{\text {age }}\right)^{2}}
$$

Foliar Hg uptake fluxes for tree species exhibiting a mean LAI values $>3$ and at sites were foliage samples were taken from top canopy calculate according to Eq. 6:

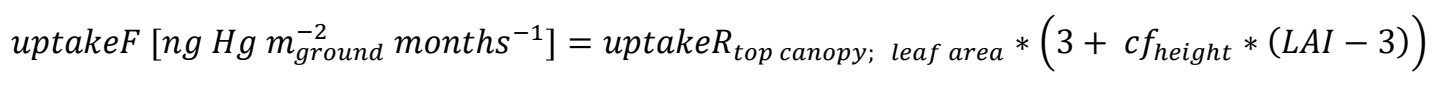

The corresponding error propagation of the flux (Eq. 3) is calculated as:

$$
\text { rel.se } e_{\text {top canopy flux;deciduous }}=\sqrt{\left(\text { rel.se } e_{\text {uptake }}\right)^{2}+\sqrt{\left(\text { rel.se } e_{\text {uptake }}\right)^{2}+\left(\text { rel.se } e_{\text {LAI }}\right)^{2}+\left(\text { rel.se } e_{\text {height }}\right)^{2}}}
$$

In case of top canopy sampled spruce with a mean LAI $>3$ the standard error of the age correction rel.se $e_{\text {age }}$ has to be taken into account:

$$
\begin{aligned}
& \text { rel.se } e_{\text {top canopy flux;spruce }} \\
& =\sqrt{\sqrt{\left(\text { rel.se } e_{\text {uptake }}\right)^{2}+\left(\text { rel.se } e_{\text {age }}\right)^{2}}+\sqrt{\left(\text { rel.se } e_{\text {uptake }}\right)^{2}+\left(\text { rel.se } e_{\text {LAI }}\right)^{2}+\left(\text { rel.se } e_{\text {height }}\right)^{2}+\left(\text { rel.se } e_{\text {age }}\right)^{2}}}
\end{aligned}
$$

The relative standard error of $\mathrm{cf}_{\text {age }}\left(\right.$ rel.se $\left._{\text {age }}\right)$ is calculated by error propagation of the relative standard errors of $\mathrm{Hg}$ accumulation rates (rel.se $\left.\mathrm{RAR}_{\mathrm{R}}\right)$ and the relative biomass of $\mathrm{n}$ needle age classes $\left(\mathrm{y}_{0}, \mathrm{y}_{1}, \ldots, \mathrm{y}_{\mathrm{n}}\right)$ (Sect. S6):

$$
\text { rel.se } e_{\text {age }}=\sqrt{\left(R B_{y 0}\right)^{2} *\left(s e_{R A R ; y 0}\right)^{2}+\left(R B_{y 1}\right)^{2} *\left(s e_{R A R ; y 1}\right)^{2}+\cdots+\left(R B_{y n}\right)^{2} *\left(s e_{R A R ; y n}\right)^{2}}
$$

The relative standard error of $\mathrm{cf}_{\text {height }}\left(\mathrm{rel}_{\text {.se }} \mathrm{height}_{\text {) }}\right.$ is calculated by error propagation of the relative standard errors of the regression slopes of $\mathrm{Hg}$ concentrations (mass $\mathrm{Hg}$ per dry weight) over sampling time (rel.se $\mathrm{e}_{\text {conc.reg.) }}$ ) in top canopy and ground foliage and the relative standard errors of mean leaf mass per area (LMA) (rel.se $\mathrm{LmA}_{\mathrm{A}}$ ) of respective top canopy and ground foliage: 


$$
\begin{aligned}
& \text { rel.se } e_{\text {height }} \\
& =\sqrt{\sqrt{\left(\text { rel.se } e_{\text {conc.reg;ground }}\right)^{2}+\left(\text { rel.se } e_{\text {conc.reg;canopy }}\right)^{2}}+\sqrt{\left(\text { rel.se } e_{L M A ; g r o u n d}\right)^{2}+\left(\text { rel. se } e_{L M A ; c a n o p y}\right)^{2}}}
\end{aligned}
$$

Both relative standard errors rel.se conc.reg. and rel.se $_{\text {LMA }}$ were calculated per tree species by using data from Hölstein. Additionally, we derived rel.se LMA $_{\text {f }}$ from LMA data by Stancioiu and O'Hara (2006) for spruce at Hyltemossa, Norunda and Svartberget because LMA values by Stancioiu and O'Hara (2006) were more generically determined for a range of trees of various height, diameter and age. Stancioiu and O'Hara (2006) fitted a curve to their LMA data reading:

$$
L M A^{-1}=a+b * \ln (P A C L)
$$

with PACL denoting the percentage of above canopy light (for top canopy foliage samples we generically set PACL $=90 \%$ and for ground samples PACL $=10 \%$ ). Using the standard error of the intercept a and the standard error of the slope b rel.se LMA $_{\text {reads: }}$

$$
\text { rel.se } e_{L M A}=\sqrt{\left.\left(\text { rel.se } e_{a}\right)^{2}+\ln (P A C L)^{2} *(\text { rel.se })_{b}\right)^{2}}
$$

Mean foliar $\mathrm{Hg}$ uptake fluxes per tree species were obtained by averaging species-specific foliar Hg uptake fluxes over multiple sites. For sites where foliage samples were taken from the tree canopy averaging over multiple sites per tree species was only possible for pine and spruce as beech and oak were exclusively sampled at one site (Hölstein). The standard error of mean foliar Hg uptake flux per species (pine/spruce) calculates as

$$
\text { se } e_{\text {flux per species }}=\sqrt{\left(\text { se } e_{\text {uptake } ; \text { site } 1}\right)^{2}+\left(\text { se } e_{\text {uptake } ; \text { site } 2}\right)^{2}+\cdots+\left(\text { se } e_{\text {uptake; } ; \text { site } n}\right)^{2}}
$$

with $\mathrm{n}$ being the number of sites.

The average foliar $\mathrm{Hg}$ uptake flux per unit ground area for Europe was determined as the average foliar Hg uptake flux of different tree species weighted with the relative proportion (rel.prop.) of the respective tree species in Europe. The corresponding standard error of the flux calculates as

se average flux Europe

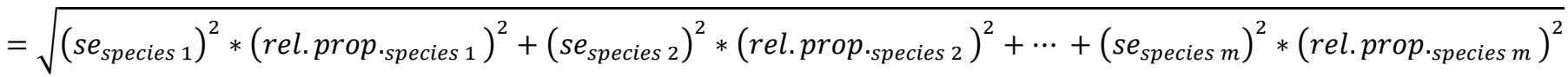

with $\mathrm{m}$ being the number of species.

In a final step the average foliar Hg uptake flux for Europe is extrapolated to Europe by multiplication with the forested land area of Europe. Thus the standard error of this extrapolated value is equally multiplied with the forested land area of Europe.

Sources of error that we could not be quantified in this study was the uncertainty of the proportion of tree species in Europe which was taken from Brus et al. (2012) and possible unknown biases during sampling. Additionally, it is currently not quantified to which extend the physiological status of trees e.g. regarding drought stress impacts foliar Hg uptake rates. 


\section{References of Supplementary Material}

Brus, D. J., Hengeveld, G. M., Walvoort, D. J. J., Goedhart, P. W., Heidema, A. H., Nabuurs, G. J. and Gunia, K.: Statistical mapping of tree species over Europe, Eur. J. For. Res., 131(1), 145-157, doi:10.1007/s10342-011-0513-5, 2012.

Eriksson, H., Eklundh, L., Hall, K. and Lindroth, A.: Estimating LAI in deciduous forest stands, Agric. For. Meteorol., 129(1), 27-37, doi:10.1016/j.agrformet.2004.12.003, 2005.

Eurostat: European Commission forestry database: Area of wooded land (source: FAO - FE), [online] Available from: https://appsso.eurostat.ec.europa.eu/nui/submitViewTableAction.do, 2015.

FAO: Global Forest Resources Assessment 2015. Country Report, Belarus. Food and Agricultural Organization of the United Nations, 2014a.

FAO: Global Forest Resources Assessment 2015. Country report, Ukraine, Food Agric. Organ. U. N., 2014b.

Iio, A. and Ito, A.: A global database of field-observed leaf area index in woody plant species, 1932 - 2011. Data set available online from Oak Ridge National Laboratory Distributed Active Archive Center, Oak Ridge, Tennessee, USA, Oak Ridge, doi:https://daac.ornl.gov/cgi-bin/dsviewer.pl?ds_id=1231, 2014.

Ku, H. H.: Notes on the use of propagation of error formulas, J. Res. Natl. Bur. Stand., 70C(4), 1966.

Loustau, D., Altimir, N., Barbaste, M., Gielen, B., Jiménez, S. M., Klumpp, K., Linder, S., Matteucci, G., Merbold, L., Op de Beeck, M., Soulé, P., Thimonier, A., Vincke, C. and Waldner, P.: Sampling and collecting foliage elements for the determination of the foliar nutrients in ICOS ecosystem stations, Int. Agrophysics, 32, 665-676, doi:doi: 10.1515/intag-2017-0038, 2018.

Matyssek, R., Reich, P., Oren, R. and Winner, W. E.: 9 - Response Mechanisms of Conifers to Air Pollutants, in Ecophysiology of Coniferous Forests, edited by W. K. Smith and T. M. Hinckley, pp. 255-308, Academic Press, San Diego., 1995.

McLagan, D. S., Mitchell, C. P. J., Huang, H., Lei, Y. D., Cole, A. S., Steffen, A., Hung, H. and Wania, F.: A highprecision passive air sampler for gaseous mercury, Environ. Sci. Technol. Lett., 3(1), 24-29, doi:10.1021/acs.estlett.5b00319, 2016.

McLagan, D. S., Huang, H., Lei, Y. D., Wania, F. and Mitchell, C. P. J.: Application of sodium carbonate prevents sulphur poisoning of catalysts in automated total mercury analysis, Spectrochim. Acta Part B At. Spectrosc., 133, 60-62, doi:10.1016/j.sab.2017.04.014, 2017a.

McLagan, D. S., Mitchell, C. P. J., Huang, H., Abdul Hussain, B., Lei, Y. D. and Wania, F.: The effects of meteorological parameters and diffusive barrier reuse on the sampling rate of a passive air sampler for gaseous mercury, Atmospheric Meas. Tech., 10(10), 3651-3660, doi:https://doi.org/10.5194/amt-10-3651-2017, $2017 \mathrm{~b}$.

McLagan, D. S., Steffen, A., Hung, H., Shin, C., Stupple, G. W., Olson, M. L., Luke, W. T., Kelley, P., Howard, D., Edwards, G. C., Nelson, P. F., Xiao, H., Sheu, G.-R., Dreyer, A., Huang, H., Abdul Hussain, B., Lei, Y. D., Tavshunsky, I. and Wania, F.: Global evaluation and calibration of a passive air sampler for gaseous mercury, Atmos Chem Phys, 18(8), 5905-5919, doi:10.5194/acp-18-5905-2018, 2018.

NIBIO: Landsskogtakseringen. Norway’s National Forest Inventory Database, Nor. Inst. Bioeconomy Res., doi:https://landsskog.nibio.no/, 2016.

Papula, L.: Mathematische Formelsammlung für Ingenieure und Naturwissenschaftler, 8th ed., Vieweg., 2003.

Poorter, H., Niinemets, Ü., Poorter, L., Wright, I. J. and Villar, R.: Causes and consequences of variation in leaf mass per area (LMA): a meta-analysis, New Phytol., 182(3), 565-588, doi:10.1111/j.1469-8137.2009.02830.x, 2009. 
Rigling, A. and Schaffer, H. P.: Forest Report 2015. Condition and use of Swiss forests., FOEN WSL, 2015.

Stancioiu, P. T. and O'Hara, K. L.: Morphological plasticity of regeneration subject to different levels of canopy cover in mixed-species, multiaged forests of the Romanian Carpathians, Trees, 20(2), 196-209, doi:10.1007/s00468005-0026-2, 2006.

Tyrrell, M. L., Ross, J. and Kelty, M.: Carbon dynamics in the Temperate Forest, in Managing Forest Carbon in a Changing Climate, edited by M. S. Ashton, M. L. Tyrrell, D. Spalding, and B. Gentry, pp. 77-107, Springer Netherlands, Dordrecht., 2012. 